\title{
PROPAGATION OF JACKFRUIT BY MODIFIED CLEFT GRAFTING AS INFLUENCED BY TIME OF OPERATION
}

\author{
M. J. M. Khatun ${ }^{1}$, M. S. Islam, T. Haque and N. Khan \\ Department of Horticulture, Bangladesh Agricultural University \\ Mymensingh-2202, Bangladesh
}

\begin{abstract}
The experiment was conducted to study the effect of time (season) of grafting on the performance of modified cleft grafting of Jackfruit at the BAU Germplasm Centre (GPC) of Fruit Tree Improvement Project (FTIP) of the Department of Horticulture, Bangladesh Agricultural University, Mymensingh. The experiment consisting ten levels of grafting times, viz., 30 $0^{\text {th }}$ March, $15^{\text {th }}$ April, 30 $0^{\text {th }}$ April, $15^{\text {th }}$ May, $30^{\text {th }}$ May, $15^{\text {th }}$ June, $30^{\text {th }}$ June, $15^{\text {th }}$ July, $30^{\text {th }}$ July, $15^{\text {th }}$ August, was laid out in RCBD with three replications. The results revealed that grafting done on $14^{\text {th }}$ August showed the highest success (39\%) and took the lowest time to first flush and first leaf opening (4.66 and 5.00 days, respectively) whereas the success rates were very low at the months of March, April and May. Likewise the highest vegetative growth of the grafted plants in terms of height, diameter, number of leaves, length and breadth of the leaves was found with grafting done on $14^{\text {th }}$ August.
\end{abstract}

Key words : Jackfruit, Grafting, Season, Success, Growth

\section{INTRODUCTION}

The largest fruit of the world, Jackfruit (Artocarpus heterophyllus Lam.) is the national fruit of Bangladesh which occupied about 68 thousand acres. The production is about 279 thousand metric tons of fruits annually in Bangladesh (BBS, 2005). Due to reasonable market price, taste and availability this is very popular to the people of all levels. Being such an important crop there is no recommended variety of Jackfruit in Bangladesh.

Cross-pollinated crop Jackfruit is habitually propagated through seed (Samaddar, 1990) which ultimately follow-on a number of heterozygous trees throughout the country. To get true to type plant, vegetative propagation is the only way (Bose and Mitra, 1990). But still, from different research work jackfruit is considered as a more difficult species to propagate by vegetative means compared to the other fruit plants. The main reason is possibly due to its latex, which hinders the normal process of callus formation and ultimately the graft union (Soepadmo 1991). Cutting could not be an acceptable method for commercial propagation of jackfruit due to high rate of mortality. Air layering and budding are also considered as very hard method as the success rate is very low (RoweDutton, 1976). On the other hand layering requires growth hormone for root initiation. Recently, success of epicotyl and cleft grafting has been reported by a number of authors (Jose and Velsalakumari, 1991; Kuddus, 2001). Among the different important factors 
affecting the success of grafting, time and method of grafting, age of rootstock and scion are very important for tropical fruit plants like mango and jackfruit (Islam et. al. 2004; Kumar et al. 2000; Azad, 1999). Considering the above facts, attempts were taken to find out the appropriate time of modified cleft grafting to get a suitable and easy method of jackfruit propagation.

\section{MATERIALS AND METHODS}

The experiment on modified cleft grafting of Jackfruit was conducted at the BAU Germplasm Centre (GPC) of Fruit Tree Improvement Project (FTIP) of the Department of Horticulture, Bangladesh Agricultural University, Mymensingh. Scions with deep green leaves were selected from healthy, quality, vigorous and actively growing shoots of 10 years old Accession No. $\mathrm{Ah}_{68}$ from Germplasm Centre of Fruit Tree Improvement Project (FTIP) of Department of Horticulture, BAU. Rootstocks were used from GPC, planted in the previous year. The single factor experiment consisting ten levels of grafting times,

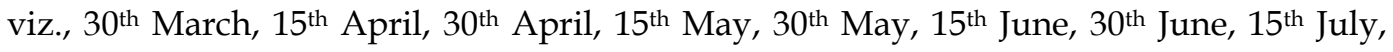
$30^{\text {th }}$ July, $15^{\text {th }}$ August, was laid out in RCBD with three replications. Each replication was consisted of ten grafts.

The prepared grafts were placed under shade and were maintained in good condition by watering, removal of polythene cap and sheet after sprouting, weeding, and off shoot cutting. Sometimes the shades were removed for the exposure of the grafts to the sunlight. The data were collected on the following parameters: success of grafting, time required to first flush, scion height, scion diameter, number of leaves per graft, leaf length and leaf breadth. Number of successful grafts and average time required to first flush were calculated from date of operation. Growths of the grafts (scion height, scion diameter, number of leaves, leaf length and leaf breadth) were recorded at 15 days interval up to 150 days after grafting operation. Data were collected on various parameters as mentioned in the tables and the differences of the mean of treatments were compared by LSD test (Gomez and Gomez, 1993).

\section{RESULTS AND DISCUSSION}

\section{Percent of success of grafts}

The success of jackfruit grafts varied significantly due to the different times (months) of operation. The highest success $(39.00 \%)$ was recorded in $14^{\text {th }}$ August operation whereas, there was no success in some times specially during the hot summer (Table 1). The differences in the success might be due to the prevalence of varied climatic conditions during grafting operation. The highest success in $14^{\text {th }}$ August was possibly due to availability of dormant scion at that time and more humidity in environment, on the other hand during early summer (March to May) the environment was excessively dry which caused the death of scion before union formation. The findings also corroborated with the results of Patel and Amin (1976). 


\section{Days required to first flush and leaf opening}

Time of operation had significant influence on the days required to $1^{\text {st }}$ flush and1 $1^{\text {st }}$ leaf opening of the grafts. Grafting operation done in $14^{\text {th }}$ August took the lowest time (4.66 and 5.00 days respectively) to first flush and first leaf opening, whereas it was the highest (55.66 and 57.00 days respectively) in case of $13^{\text {th }}$ June grafting (Table 1 ). This findings might be related to the maturity of scion bud, which was the highest in August and less in earlier months.

Table 1. Main effect of time of operation on the percent success, days required to 1st flush and leaf opening of modified cleft grafting in Jackfruit

\begin{tabular}{|c|c|c|c|}
\hline \multirow[t]{2}{*}{ Time of operation } & \multirow[t]{2}{*}{ Percent of success } & \multicolumn{2}{|c|}{ Days required } \\
\hline & & for $1^{\text {st }}$ flash & to leaf opening \\
\hline 30th March & 0.00 & 0.00 & 0.00 \\
\hline 14th April & 0.00 & 0.00 & 0.00 \\
\hline 29th April & 5.66 & 23.55 & 24.55 \\
\hline $14^{\text {th }}$ May & 0.00 & 0.00 & 0.00 \\
\hline 29th May & 5.66 & 24.88 & 26.67 \\
\hline $13^{\text {th }}$ June & 28.00 & 55.66 & 57.00 \\
\hline $28^{\text {th }}$ June & 0.00 & 0.00 & 0.00 \\
\hline $13^{\text {th }}$ July & 11.33 & 17.67 & 18.00 \\
\hline 29th July & 28.00 & 12.00 & 12.83 \\
\hline 14th August & 39.00 & 4.66 & 5.00 \\
\hline LSD at $1 \%$ & 10.20 & 7.85 & 8.04 \\
\hline Level of significance & $* *$ & $* *$ & $* *$ \\
\hline
\end{tabular}

** Significant at $1 \%$ level

\section{Subsequent growth of the grafts}

To study the performance of successful grafts the vegetative growth was observed intensively providing 15 days interval up to 150 days after grafting. The recorded data showed that the time of operation of modified cleft grafting had significant influence on vegetative growth of the grafts which are discussed below.

\section{Height and Diameter of scion}

Time of grafting exerted a significant influence on the height and diameter of scion at different date after grafting operations (Table 2). After 150 days of grafting the highest scion height $(24.13 \mathrm{~cm})$ was found in the grafts made in $14^{\text {th }}$ August. The lowest scion height $(7.57 \mathrm{~cm})$ was recorded in $29^{\text {th }}$ April operation. Similarly diameter of scion was also significantly varied due to the influence of time of operation. The highest diameter of scion $(0.47 \mathrm{~cm})$ was observed in case of $14^{\text {th }}$ August grafting at 150 DAG (Table 3). 
Growth of the scion (growth of grafted plant) were maximum with the grafts operated at the month of August might be due to the appropriate maturity of bud which led to the early flushing and early establishment of union. Furthermore, appropriate climatic condition like high temperature and humidity might increase the cell division and decrease the water loss from the scion, respectively.

Table 2. Performance of different time of operation on the height of scion for modified cleft grafting in Jackfruit

\begin{tabular}{|c|c|c|c|c|c|c|c|c|c|c|}
\hline \multirow{2}{*}{$\begin{array}{l}\text { Time of } \\
\text { operation }\end{array}$} & \multicolumn{10}{|c|}{ Height of scion $(\mathrm{cm})$ at different days after grafting } \\
\hline & 15 days & 30 days & 45 days & 60 days & 75 days & 90 days & $\begin{array}{c}105 \\
\text { days }\end{array}$ & $\begin{array}{c}120 \\
\text { days }\end{array}$ & $\begin{array}{c}135 \\
\text { days }\end{array}$ & $\begin{array}{c}150 \\
\text { days }\end{array}$ \\
\hline $13^{\text {th }}$ March & 0.00 & 0.00 & 0.00 & 0.00 & 0.00 & 0.00 & 0.00 & 0.00 & 0.00 & 0.00 \\
\hline $14^{\text {th }}$ April & 0.00 & 0.00 & 0.00 & 0.00 & 0.00 & 0.00 & 0.00 & 0.00 & 0.00 & 0.00 \\
\hline 29th April & 5.57 & 6.00 & 6.76 & 6.77 & 6.77 & 7.00 & 7.17 & 7.33 & 7.33 & 7.57 \\
\hline 14th May & 0.00 & 0.00 & 0.00 & 0.00 & 0.00 & 0.00 & 0.00 & 0.00 & 0.00 & 0.00 \\
\hline 29th May & 6.43 & 7.65 & 8.16 & 8.17 & 8.17 & 8.33 & 8.50 & 8.67 & 8.67 & 8.83 \\
\hline $13^{\text {th }}$ June & 14.47 & 17.10 & 18.10 & 18.60 & 19.27 & 19.67 & 20.07 & 20.37 & 21.40 & 21.73 \\
\hline 28th June & 0.00 & 0.00 & 0.00 & 0.00 & 0.00 & 0.00 & 0.00 & 0.00 & 0.00 & 0.00 \\
\hline $13^{\text {th }}$ July & 6.67 & 7.60 & 8.16 & 10.50 & 10.50 & 13.23 & 16.13 & 18.13 & 19.70 & 20.73 \\
\hline 29th July & 8.40 & 11.67 & 13.06 & 15.00 & 16.06 & 18.00 & 18.50 & 19.40 & 21.00 & 23.00 \\
\hline 14th August & 6.70 & 6.90 & 7.83 & 10.17 & 10.17 & 11.83 & 13.50 & 17.90 & 21.70 & 24.13 \\
\hline LSD at $1 \%$ & 4.57 & 5.68 & 6.30 & 6.60 & 6.74 & 7.38 & 7.90 & 8.48 & 9.78 & 10.39 \\
\hline $\begin{array}{l}\text { Level of } \\
\text { significance }\end{array}$ & $* *$ & ** & $* *$ & ** & $* *$ & ** & ** & $* *$ & $* *$ & $* *$ \\
\hline
\end{tabular}

** Significant at $1 \%$ level

\section{Number of leaves per graft}

Number of leaves per graft was also highly influenced by time of operation. From the very beginning to 150 days after grafting (DAG), grafts done at August $14^{\text {th }}$ produced the highest number of leaves per grafts which reached at 25 leaves at 150 DAG (Table 4). Whereas, April 29 and May 29 gave the minimum number of leaves at 150 DAG. The result is similar to that of Rahim et al. (1984). Maximum number of leaves with the grafts done in the month of August might be due to optimum temperature and soil moisture that was effective for maximum cell division. Another cause might be early bud breaking. The largest leaves (maximum length and breadth) were obtained in grafting operation at $14^{\text {th }}$ August probably due to early sprouting and availed maximum duration up to 150 DAG. 
Table 3. Performance of different time of operation on the diameter of scion for modified cleft grafting in Jackfruit

\begin{tabular}{|c|c|c|c|c|c|c|c|c|c|c|}
\hline \multirow{2}{*}{$\begin{array}{c}\text { Time of } \\
\text { operation }\end{array}$} & \multicolumn{10}{|c|}{ Diameter of scion $(\mathrm{cm})$ at different days after grafting } \\
\hline & 15 days & 30 days & 45 days & 60 days & 75 days & 90 days & $\begin{array}{c}105 \\
\text { days }\end{array}$ & $\begin{array}{c}120 \\
\text { days }\end{array}$ & $\begin{array}{c}135 \\
\text { days }\end{array}$ & $\begin{array}{c}150 \\
\text { days }\end{array}$ \\
\hline 13th March & 0.00 & 0.00 & 0.00 & 0.00 & 0.00 & 0.00 & 0.00 & 0.00 & 0.00 & 0.00 \\
\hline 14 $4^{\text {th }}$ April & 0.00 & 0.00 & 0.00 & 0.00 & 0.00 & 0.00 & 0.00 & 0.00 & 0.00 & 0.00 \\
\hline 29th April & 0.13 & 0.13 & 0.13 & 0.13 & 0.14 & 0.14 & 0.14 & 0.14 & 0.15 & 0.15 \\
\hline 14th May & 0.00 & 0.00 & 0.00 & 0.00 & 0.00 & 0.00 & 0.00 & 0.00 & 0.00 & 0.00 \\
\hline 29th May & 0.16 & 0.16 & 0.16 & 0.16 & 0.16 & 0.18 & 0.18 & 0.19 & 0.19 & 0.19 \\
\hline $13^{\text {th }}$ June & 0.33 & 0.35 & 0.34 & 0.38 & 0.40 & 0.42 & 0.42 & 0.45 & 0.45 & 0.45 \\
\hline 28 $8^{\text {th }}$ June & 0.00 & 0.00 & 0.00 & 0.00 & 0.00 & 0.00 & 0.00 & 0.00 & 0.00 & 0.00 \\
\hline 13th July & 0.25 & 0.27 & 0.28 & 0.29 & 0.29 & 0.29 & 0.31 & 0.31 & 0.31 & 0.31 \\
\hline 29th July & 0.29 & 0.29 & 0.33 & 0.36 & 0.37 & 0.37 & 0.39 & 0.41 & 0.41 & 0.42 \\
\hline $14^{\text {th }}$ August & 0.41 & 0.44 & 0.44 & 0.44 & 0.45 & 0.47 & 0.47 & 0.47 & 0.47 & 0.47 \\
\hline LSD at $1 \%$ & 0.12 & 0.13 & 0.13 & 0.13 & 0.13 & 0.13 & 0.13 & 0.14 & 0.14 & 0.14 \\
\hline $\begin{array}{l}\text { Level of } \\
\text { significance }\end{array}$ & $* *$ & $* *$ & $* *$ & $* *$ & $* *$ & $* *$ & $* *$ & $* *$ & $* *$ & $* *$ \\
\hline
\end{tabular}

** Significant at $1 \%$ level

Table 4. Performance of different time of operation on the number of leaves for modified cleft grafting in Jackfruit

\begin{tabular}{|c|c|c|c|c|c|c|c|c|c|c|}
\hline \multirow{2}{*}{$\begin{array}{l}\text { Time of } \\
\text { operation }\end{array}$} & \multicolumn{10}{|c|}{ Number of leaves at different days after grafting } \\
\hline & 15 days & 30 days & 45 days & 60 days & 75 days & 90 days & $\begin{array}{c}105 \\
\text { days }\end{array}$ & $\begin{array}{l}120 \\
\text { days }\end{array}$ & $\begin{array}{c}135 \\
\text { days }\end{array}$ & $\begin{array}{l}150 \\
\text { days }\end{array}$ \\
\hline $13^{\text {th }}$ March & 0.00 & 0.00 & 0.00 & 0.00 & 0.00 & 0.00 & 0.00 & 0.00 & 0.00 & 0.00 \\
\hline $14^{\text {th }}$ April & 0.00 & 0.00 & 0.00 & 0.00 & 0.00 & 0.00 & 0.00 & 0.00 & 0.00 & 0.00 \\
\hline 29th April & 3.00 & 3.33 & 3.33 & 3.33 & 4.00 & 4.33 & 5.00 & 5.67 & 6.33 & 7.33 \\
\hline $14^{\text {th }}$ May & 0.00 & 0.00 & 0.00 & 0.00 & 0.00 & 0.00 & 0.00 & 0.00 & 0.00 & 0.00 \\
\hline 29th May & 2.33 & 2.67 & 2.67 & 2.67 & 3.00 & 3.33 & 4.00 & 4.67 & 5.33 & 5.67 \\
\hline $13^{\text {th }}$ June & 2.00 & 3.00 & 4.00 & 4.67 & 5.67 & 7.00 & 8.00 & 9.00 & 9.00 & 10.00 \\
\hline 28th June & 0.00 & 0.00 & 0.00 & 0.00 & 0.00 & 0.00 & 0.00 & 0.00 & 0.00 & 0.00 \\
\hline $13^{\text {th }}$ July & 3.00 & 4.00 & 3.33 & 5.00 & 7.67 & 8.33 & 10.00 & 11.33 & 13.00 & 15.00 \\
\hline 29th July & 1.67 & 3.00 & 3.33 & 4.33 & 5.67 & 7.33 & 8.33 & 9.33 & 10.33 & 10.33 \\
\hline $14^{\text {th }}$ August & 8.00 & 9.67 & 9.67 & 9.67 & 12.67 & 14.67 & 17.33 & 19.00 & 21.67 & 25.00 \\
\hline LSD at $1 \%$ & 2.32 & 2.48 & 2.42 & 2.53 & 3.19 & 3.53 & 1.26 & 4.94 & 5.56 & 6.32 \\
\hline $\begin{array}{l}\text { Level of } \\
\text { significance }\end{array}$ & $* *$ & $* *$ & $* *$ & ** & $* *$ & $* *$ & $* *$ & $* *$ & $* *$ & $* *$ \\
\hline
\end{tabular}

** Significant at $1 \%$ level 


\section{Length of leaves per graft}

Time of operation also significantly increased the length of leaf of the graft. Length of leaf was found to be the highest $(10.76 \mathrm{~cm})$ in the grafts done at $14^{\text {th }}$ August which was closely followed by $29^{\text {th }}$ July $(10.24 \mathrm{~cm})$ and $13^{\text {th }}$ June $(10.07 \mathrm{~cm})$. On the other hand it was the lowest $(2.89 \mathrm{~cm})$ in $29^{\text {th }}$ April grafting (Table 5).

Table 5. Performance of different time of operation on the length of leaf for modified cleft grafting in Jackfruit

\begin{tabular}{|c|c|c|c|c|c|c|c|c|c|c|}
\hline \multirow{2}{*}{$\begin{array}{c}\text { Time of } \\
\text { operation }\end{array}$} & \multicolumn{10}{|c|}{ Length of leaf $(\mathrm{cm})$ at different days after grafting } \\
\hline & 15 days & 30 days & 45 days & 60 days & 75 days & 90 days & $\begin{array}{c}105 \\
\text { days }\end{array}$ & $\begin{array}{c}120 \\
\text { days }\end{array}$ & $\begin{array}{c}135 \\
\text { days }\end{array}$ & $\begin{array}{c}150 \\
\text { days }\end{array}$ \\
\hline 13th March & 0.00 & 0.00 & 0.00 & 0.00 & 0.00 & 0.00 & 0.00 & 0.00 & 0.00 & 0.00 \\
\hline $14^{\text {th }}$ April & 0.00 & 0.00 & 0.00 & 0.00 & 0.00 & 0.00 & 0.00 & 0.00 & 0.00 & 0.00 \\
\hline 29th April & 1.79 & 1.70 & 1.83 & 2.01 & 2.83 & 2.43 & 2.45 & 2.86 & 2.89 & 2.89 \\
\hline $14^{\text {th }}$ May & 0.00 & 0.00 & 0.00 & 0.00 & 0.00 & 0.00 & 0.00 & 0.00 & 0.00 & 0.00 \\
\hline 29th May & 3.06 & 3.60 & 3.55 & 3.53 & 3.50 & 3.55 & 3.73 & 3.77 & 3.88 & 3.95 \\
\hline $13^{\text {th }}$ June & 3.37 & 4.97 & 6.82 & 7.25 & 6.92 & 7.65 & 7.55 & 8.56 & 9.70 & 10.07 \\
\hline 28th June & 0.00 & 0.00 & 0.00 & 0.00 & 0.00 & 0.00 & 0.00 & 0.00 & 0.00 & 0.00 \\
\hline $13^{\text {th }}$ July & 6.18 & 7.76 & 6.68 & 7.66 & 7.76 & 7.56 & 7.81 & 7.95 & 8.25 & 8.25 \\
\hline $29^{\text {th }}$ July & 5.67 & 7.14 & 7.80 & 7.94 & 7.72 & 8.74 & 9.22 & 9.87 & 10.64 & 10.76 \\
\hline $14^{\text {th }}$ August & 7.28 & 8.26 & 8.24 & 8.40 & 8.58 & 8.79 & 6.11 & 9.99 & 10.17 & 10.24 \\
\hline LSD at $1 \%$ & 2.56 & 2.91 & 2.80 & 2.92 & 3.07 & 3.03 & 3.15 & 3.32 & 3.46 & 3.41 \\
\hline $\begin{array}{l}\text { Level of } \\
\text { significance }\end{array}$ & $* *$ & ** & $* *$ & $* *$ & ** & $* *$ & $* *$ & $* *$ & ** & $* *$ \\
\hline
\end{tabular}

** Significant at $1 \%$ level

\section{Breadth of leaves per graft}

Breadth of leaves was also significantly varied due to the influence of time of operation. The highest breadth of leaf $(5.14 \mathrm{~cm})$ was recorded in case of $14^{\text {th }}$ August grafting followed by $29^{\text {th }}$ July $(5.03 \mathrm{~cm})$ grafting at 150 DAG. The lowest breadth of leaf $(1.46 \mathrm{~cm})$ was recorded in $29^{\text {th }}$ April grafting at 150 DAG (Table 6).

Considering the parameters it was observed from this research work that mid August is the optimum time for modified cleft grafting in Jackfruit as at this time the success and subsequent growth of grafts is relatively better. The research may be done further for better confirmation and with new dimension. 
Table 6. Performance of different time of operation on the breadth of leaf for modified cleft grafting in Jackfruit

\begin{tabular}{|c|c|c|c|c|c|c|c|c|c|c|}
\hline \multirow{2}{*}{$\begin{array}{c}\text { Time of } \\
\text { operation }\end{array}$} & \multicolumn{10}{|c|}{ Breadth of leaf $(\mathrm{cm})$ at different days after grafting } \\
\hline & 15 days & 30 days & 45 days & 60 days & 75 days & 90 days & $\begin{array}{l}105 \\
\text { days }\end{array}$ & $\begin{array}{c}120 \\
\text { days }\end{array}$ & $\begin{array}{c}135 \\
\text { days }\end{array}$ & $\begin{array}{c}150 \\
\text { days }\end{array}$ \\
\hline 13 th March & 0.00 & 0.00 & 0.00 & 0.00 & 0.00 & 0.00 & 0.00 & 0.00 & 0.00 & 0.00 \\
\hline $14^{\text {th }}$ April & 0.00 & 0.00 & 0.00 & 0.00 & 0.00 & 0.00 & 0.00 & 0.00 & 0.00 & 0.00 \\
\hline 29th April & 0.10 & 1.19 & 1.01 & 1.10 & 1.11 & 1.20 & 1.22 & 1.40 & 1.44 & 1.45 \\
\hline $14^{\text {th }}$ May & 0.00 & 0.00 & 0.00 & 0.00 & 0.00 & 0.00 & 0.00 & 0.00 & 0.00 & 0.00 \\
\hline 29th May & 1.56 & 1.84 & 1.77 & 1.79 & 1.78 & 1.77 & 1.87 & 1.88 & 1.96 & 1.98 \\
\hline $13^{\text {th }}$ June & 3.89 & 4.53 & 4.39 & 4.37 & 4.30 & 4.40 & 4.73 & 4.99 & 4.81 & 4.87 \\
\hline 28th June & 0.00 & 0.00 & 0.00 & 0.00 & 0.00 & 0.00 & 0.00 & 0.00 & 0.00 & 0.00 \\
\hline $13^{\text {th }}$ July & 3.04 & 3.90 & 3.48 & 4.10 & 4.13 & 0.04 & 4.11 & 4.14 & 4.27 & 4.24 \\
\hline 29th July & 2.55 & 3.51 & 3.95 & 4.04 & 4.16 & 4.61 & 4.78 & 4.97 & 5.19 & 5.03 \\
\hline $14^{\text {th }}$ August & 1.70 & 2.47 & 3.55 & 3.98 & 3.87 & 4.02 & 4.31 & 4.66 & 4.96 & 5.14 \\
\hline LSD at $1 \%$ & 1.32 & 1.51 & 1.37 & 1.56 & 1.63 & 1.56 & 1.62 & 1.69 & 1.78 & 1.73 \\
\hline $\begin{array}{l}\text { Level of } \\
\text { significance }\end{array}$ & $* *$ & $* *$ & $* *$ & $* *$ & $* *$ & $* *$ & $* *$ & $* *$ & $* *$ & $* *$ \\
\hline
\end{tabular}

** Significant at $1 \%$ level

\section{REFERENCES}

Azad, A. K. 1999. Genetic diversity and propagation methods of Jackfruit. Ph. D. Dissertation. University of Southampton, Southampton, UK. 158 p.

Bose, T. K. and Mitra, S. K. 1990. Fruits: Tropical and Subtropical. Naya prokash, 206, Bidhan Sarani, Calcutta. p. 642.

Gomez, K. A. and Gomez, A. A. 1993. Statistical Procedures for Agricultural Research. (2nd ed.). John Willy and Sons. New York. pp. 272-279.

M. S. Islam, A. M. Farooque, M. A. Rahim and T. Haque. 2004. Effect of Age of Rootstock and Scion Defoliation on Epicotyl Grafting in Jackfruit. Bangladesh J. Crop Sci., 13-15: 89-93.

Jose, M. and Velsalskumari, P. K. 1991. Standardization of epicotyl and softwood grafting in Jackfruit. South Indian Hort., 39(5): 264-267.

Kuddus, M. A. 2001. Characterization and grafting performance of different accessions of Jackfruit. M. S Thesis, Dept of Hort., Bangladesh Agril. Univ., Mymensingh. 118 p.

Kumar, S., Ram-Sant, Singh, C. P. and Ram, S. 2000. Success of veneer and cleft grafting at different height of seedling rootstocks in Dashehari mango. Indian J. Hort., 57(3): 212-214.

Patel. M. H. and R. S. Amin. 1976. Possibilities of bench grafting on young seedlings of mango under Ananda condition. Indian J. Hort., 33(2): 156-161

Rahim, M. A. , Choudhury, M. S. H. and Ali, M. A. 1984. Studies on veneer grafting in four cultivars of mango. Bangladesh Hort., 12(1): 17-20 
Rowe-Dutton, P. 1976. Artocarpus heterophyllus-Jackfruit. In: Propagation of tropical and subtropical fruit trees. Garner, R. T. and S. A. Chaudhury (eds.). FAO, CAB, London pp. 269-290.

Samaddar, H. N. 1990. Jackfruit. In: T. K. Bose and B. Mitra (eds.). Fruits of India, Tropical and subtropical. $1^{\text {st }}$ edn. Naya Prakash, 206-Bibhan Sarani, Calcutta, India. pp. 638-649.

Soepadmo, E. 1991. Artocarpus heterophyllus Lam. In: Plant Resources in South East Asia, No. 2. Edible fruits and Nuts, E. W. M Verheij and R. E. Coronal, eds. Wageningen, Netherlands, Pudoc: pp. 86-91.

BBS. 2001. Monthly Statistical Bulletin in Bangladesh, December 2001. Bangladesh Bureau of Statistics, Statistics Division, Ministry of Planning, Government of the Peoples Republic of Bangladesh. p. 49. 